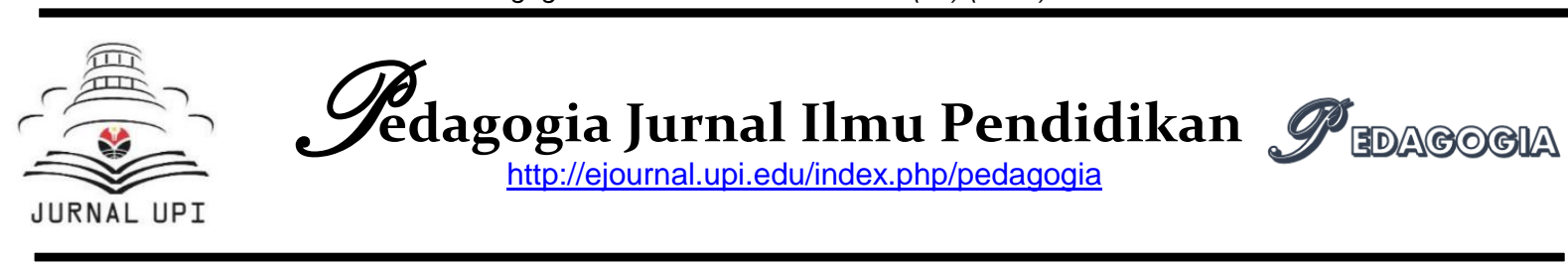

\title{
Persepsi Siswa Terhadap Penggunaan Plickers dalam Penilaian Hasil Belajar Kimia di Era Digital
}

\author{
Krisna Raditya Pratama \\ Departemen Teknologi Pendidikan \\ Fakultas Keguruan dan IImu Pendidikan \\ Universitas Sebelas Maret \\ krisnaradityapratama@student.uns.ac.id
}

\begin{abstract}
A b s tract
A formative assessment needs to be conducted at the end of each topic discussion to know the progress of some learning activity, but teachers often skip it because of limited time and cost. Plickers (Paper Clickers) is a formative assessment technology without requiring students to bring electronic devices, but rather by scanning students' responses through $Q R$ code on a card with smartphone that connected to internet. Chemistry teacher of SMK Kesehatan Wonosari was implement Plickers in formative assessment. This study aims to describe students' perception of the use of Plickers in Chemistry learning outcomes assessment in digital era. The reason for conducting this research is there is no research in Indonesia to investigate students' perceptions about the use of Plickers as an assessment of Chemistry learning outcomes. So, this study results can be used as a reference for teachers in assessing learning outcome by using Plickers. This study uses a descriptive mixed research method between quantitative and qualitative with using questionnaire instrument. This study results showed that the majority of students believed in the importance of learning outcomes assessment with Plickers because they would get immediate feedback and the learning environment become more active and enjoyable.
\end{abstract}

Keyword: Plickers, Learning Outcomes Assessment, Digital Era

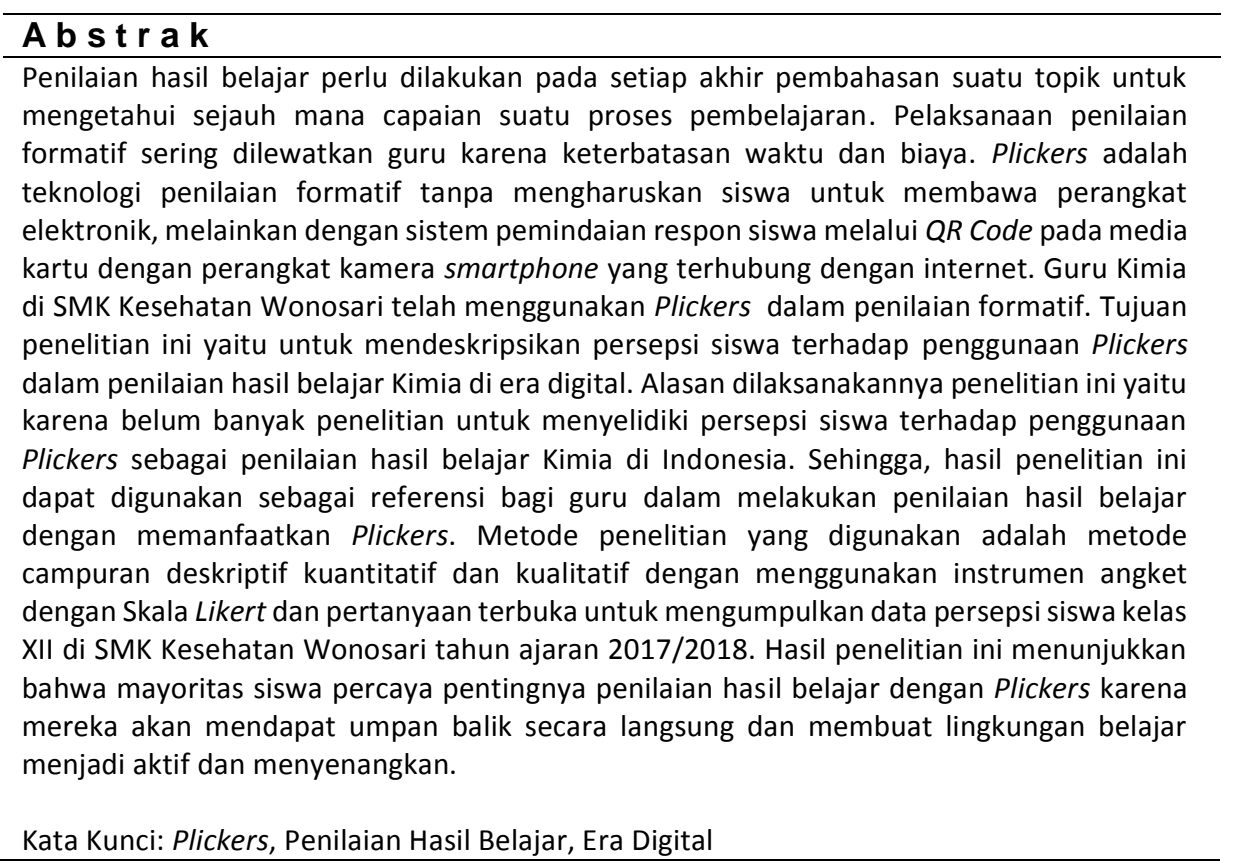

\section{Article Info}

Naskah Diterima : 2019-10-29

Naskah Direvisi: 2019-12-06

Naskah Disetujui: 2020-02-23 


\section{A. PENDAHULUAN}

Abad 21 dikenal sebagai abad pengetahuan yang ditandai dengan begitu pesatnya perkembangan teknologi dan penyebaran informasi yang kini menjadi jauh lebih cepat. Perkembangan teknologi memiliki banyak manfaat dalam berbagai bidang kehidupan salah satunya yaitu di bidang pendidikan. Menurut (Andri, 2018), teknologi adalah alat yang diciptakan untuk meringankan pekerjaan manusia supaya lebih efisien dan cepat. Perkembangan teknologi abad 21 di bidang pendidikan dapat dimanfaatkan untuk menunjang proses pembelajaran dimana guru abad 21 dituntut untuk dapat menguasai keterampilan-keterampilan yang berkaitan dengan teknologi. Tuntutan guru di abad 21 ini juga diperkuat dengan Peraturan Menteri Pendidikan Nasional No. 16 tahun 2017 yang menyebutkan bahwa untuk kepentingan penyelenggaraan kegiatan pembelajaran yang mendidik, maka kompetensi wajib yang harus dilaksanakan guru adalah memanfaatkan teknologi informasi.

Menurut International Society for Technology in Education terdapat lima kategori keterampilan guru abad 21. Salah satu keterampilan yang perlu dimiliki oleh guru abad 21 adalah mampu menyediakan alat evaluasi formatif dan sumatif yang bervariasi sesuai dengan standar teknologi dan konten yang dapat memberikan informasi yang berguna bagi proses belajar peserta didik maupun pembelajaran secara umum (Daryanto \& Karim, 2017).

Penilaian (asessment) hasil belajar merupakan komponen penting dalam kegiatan pembelajaran. Terdapat dua teknik dalam melalukan evaluasi, yaitu tes dan non-tes. Teknik tes dilakukan dengan tujuan untuk mengumpulkan informasi tentang kemampuan, penguasaan, atau aspek-aspek lain dari peserta didik dengan cara memberikan serangkaian tugas untuk dikerjakan atau dijawab oleh peserta didik. Tes memiliki banyak macam dan jenisnya.
Berdasarakan tujuan evaluasi pembelajaran, terdapat tiga macam tes yaitu tes formatif, tes sumatif, serta tes diagnostik. Tes formatif (formative test) merupakan bentuk evaluasi yang bertujuan untuk mengetahui perkembangan proses pembelajaran yang dilakukan apakah telah berjalan sesuai dengan yang direncanakan serta untuk mengontrol sejauh mana peserta didik menguasai materi yang diajarkan pada pokok bahasan tersebut. Tes formatif dapat dilakukan pada setiap akhir pembahasan satu satuan pokok bahasan (topik) atau selama proses pembelajaran masih berlangsung, sehingga dapat dilakukan dalam bentuk penilaian harian (Nurhadi \& Suwardi, 2010).

Menurut Panduan Penilaian oleh Pendidik dan Satuan Pendidikan untuk Sekolah Menengah Atas, penilaian harian merupakan penilaian hasil belajar yang dilakukan oleh pendidik. Penilaian harian dapat berupa ulangan, pengamatan, penugasan, dan bentuk lain yang diperlukan untuk mengukur dan mengetahui pencapaian kompetensi peserta didik, menetapkan program perbaikan atau pengayaan berdasarkan tingkat penguasaan kompetensi, memperbaiki proses pembelajaran, dan menyusun laporan kemajuan hasil belajar (Kemdikbud, 2017).

Cara penilaian hasil belajar peserta didik harian atau tes formatif secara tradisional yang dapat dilakukan oleh guru yaitu dengan membagikan kertas soal kepada peserta didik, kemudian peserta didik akan menjawab soal-soal yang diberikan dengan memerlukan waktu yang lama. Dalam pelaksanaan proses pembelajaran di kelas, guru atau pendidik juga dihadapkan dengan keterbatasan waktu mengajar dalam satuan jam pelajaran (JP) dan juga biaya untuk mencetak soal-soal tes yang apabila dilakukan rutin tiap pertemuan akan memerlukan biaya yang cukup membebani 
guru tersebut. Persoalan tersebut menjadi tantangan bagi para pendidik. Sehingga, untuk memecahkan permasalahan tersebut perlu adanya penggunaan teknologi dalam proses penilaian hasil belajar agar lebih cepat dan efisien. Plickers dipilih karena selain belum banyak digunakan oleh guru di Indonesia untuk menilai hasil belajar khususnya dalam mata pelajaran Kimia, Plickers memiliki kelebihan yaitu merupakan teknologi berbasis online sehingga dalam penggunaannya guru tidak perlu mencetak banyak lembar soal, proses penggunaannya mudah dan efektif, serta hasil jawaban siswa dapat langsung ditampilkan kepada siswa atau akan disimpan dalam online database yang dapat diakses kembali oleh guru. Sehingga, perbedaan penelitian ini dengan penelitian relevan lainnya yaitu pada tempat penelitian yang dilakukan di Indonesia pada mata pelajaran Kimia. Hasil penelitian ini dapat digunakan sebagai referensi bagi guru dalam melakukan penilaian hasil belajar dengan memanfaatkan teknologi Plickers .

Pemilihan media Plickers dalam penelitian ini juga dikarenakan penggunaan teknologi informasi dalam pembelajaran merupakan sesuatu yang harus dikuasai guru yang sering dikenal sebagai Technological Pedagogical and Content Knowledge (TPACK). TPACK merupakan bidang kajian yang menarik untuk diteliti bagi para pendidik atau guru di bidang teknologi Pendidikan yang salah satunya dapat dilakukan dalam bentuk penelitian survei analisis kebutuhan maupun penelitian untuk menyelidiki persepsi peserta didik (Azmina \& Solihah, 2019).

Penelitian relevan yang pernah dilakukan oleh Solmaz dan Cetin (2017) dalam jurnal yang berjudul "Ask-ResponsePlay-Learn: Student's Views on Gamification Interactive Response Systems" di Turkey memiliki tujuan untuk mengetahui persepsi siswa tentang proses pembelajaran TIK (ICT) yang diterapkan dengan metode tanya jawab berbasis aplikasi dengan aplikasi yang berbeda. Aplikasi yang dibandingkan yaitu Kahoot, Socrative dan Plicker's. Hasil penelitian ini mengungkapkan bahwa Plickers paling disukai oleh para siswa yang berpartisipasi dalam ketiga kegiatan tersebut (Solmaz \& Cetin, 2017).

Penelitian relevan lainnya yang dilakukan dengan tujuan untuk menganalisis penggunaan Plickers pada penilaian Bahasa untuk pemahaman membaca di antara para guru bahasa Inggris tahun ketiga dan keempat di sekolah-sekolah pedesaan di Malaysia menemukan bahwa Plickers dapat membantu dalam penilaian mata pelajaran Bahasa terutama pada kemampuan pemahaman membaca (Michael, Ejeng, Udit, \& Yunus, 2019).

Oleh karena itu, penggunaan Plickers dalam proses pembelajaran dapat memungkinkan guru atau pendidik untuk melakukan penilaian harian berupa tes formatif berupa soal obyektif dengan tipe soal pilihan ganda. Akan tetapi, penggunaan Plickers dalam penilaian hasil belajar peserta didik belum banyak dimanfaatkan dalam proses pembelajaran Kimia khususnya di SMK Kesehatan Wonosari.

Berdasarkan berbagai permasalahan tersebut, bagaimana persepsi siswa terhadap penggunaan Plickers dalam penilaian hasil belajar peserta didik belum diketahui. Oleh karena itu, penulis bermaksud akan melakukan penelitian yang berjudul "Persepsi Siswa terhadap Penggunaan Plickers dalam Penilaian Hasil Belajar Kimia di Era Teknologi Digital" dengan tujuan untuk mengetahui persepsi siswa terhadap penggunaan Plickers dalam penilaian hasil belajar Kimia dan juga pengaruhnya terhadap pembelajaran Kimia. Penelitian ini dilakukan karena belum ada penelitian serupa yang 
dilakukan pada mata pelajaran Kimia untuk SMK di Indonesia, sehingga temuan dari penelitian ini dapat digunakan sebagai dasar bagi guru untuk melakukan penilaian hasi belajar Kimia dengan Plickers.

\section{B. TINJAUAN PUSTAKA \\ 1. Persepsi Siswa}

Kemampuan yang dimiliki siswa untuk menangkap dan memahami suatu materi pelajaran berbeda-beda. Hal ini dipengaruhi oleh kecerdasan dan juga persepsi yang dimiliki siswa terhadap pengajar dan bagaimana proses pembelajaran yang dilakukan. Dalam (KKBI, 2019), istilah persepsi diartikan sebagai tanggapan (penerimaan) langsung dari sesuatu. Pengertian persepsi merupakan proses yang berkaitan dengan masuknya pesan atau informasi ke dalam otak melalui indera manusia (Slameto, 2010). Sedangkan, persepsi juga diartikan sebagai sebagai proses otak dalam mengatur dan menginterpretasi informasi sensoris dan memberikan makna (King, 2012).

Berdasarkan beberapa pengertian persepsi tersebut, dapat ditarik kesimpulan bahwa persepsi merupakan tanggapan atau proses penerimaan dan interpretasi suatu informasi sensoris dan pesan bermakna ke dalam otak melalui indera manusia. Apabila seseorang memiliki persepsi tentang suatu obyek dengan panca indera berarti seseorang tersebut mengetahui, memahami, dan menyadari tentang obyek tersebut. Sehingga, persepsi siswa dapat diartikan sebagai suatu proses dimana siswa menginterpretasi serta memberikan respon atau tanggapan terhadap rangsangan atau stimulus pada materi pelajaran. Respon ini dapat berupa pendapat, tindakan, atau bahkan penolakan terhadap suatu stimulus. Persepsi siswa terhadap metode resitasi atau penugasan mempengaruhi sikap dan perilaku siswa tersebut. Apabila siswa memiliki persepsi positif, maka sikap dan perilaku terhadap tugas yang dia terima akan baik, begitu juga sebaliknya.

Persepsi seseorang terhadap suatu obyek yang sama dapat berbeda-beda. Perbedaan persepsi tersebut dapat dipengaruhi oleh beberapa faktor. Faktorfaktor yang mempengaruhi persepsi terbagi menjadi faktor internal dan faktor eksternal. Faktor internal meliputi proses belajar, motivasi, kepribadian. Sedangkan, yang termasuk faktor eksternal yaitu intensitas, ukuran, keberlawanan atau kontras, pengulangan (repetition), Gerakan (moving), baru (familier) (Thoha, 2009).

\section{Penilaian (Assessment) Hasil Belajar}

Penilaian (assessment) hasil belajar merupakan komponen penting dalam kegiatan pembelajaran. Penilaian atau asesmen dapat diartikan sebagai kegiatan menafsirkan data hasil pengukuran berdasarkan kriteria maupun aturan-aturan tertentu. Dalam kaitannya dengan konteks hasil belajar, penilaian merupakan kegiatan menafsirkan data hasil pengukuran tentang kecakapan siswa yang diperoleh dari proses pembelajaran. Secara umum, penilaian hasil belajar dapat dilakukan dengan tes (tes tertulis, tes lisan, dan tes perbuatan), pemberian tugas, penilaian kinerja, penilaian proyek, penilaian hasil kerja, penilaian sikap, dan penilaian portofolio (Widoyoko, 2017).

\section{Plickers}

Plickers merupakan salah satu teknologi berbasis sistem respon interaktif (Interactive Response System) yang digunakan untuk mengirimkan respons peserta didik kepada pendidik melalui komputer, perangkat seluler, dan kartu dengan kode QR (Solmaz \& Cetin, 2017). Plickers dapat digunakan untuk melibatkan siswa atau peserta didik dari segala usia dalam penilaian formatif, hal ini unik karena dapat dilakukan untuk menilai semua jawaban sekaligus secara bersamaan 
hanya dengan mengkangkat kartu berisi kode QR (Kent, 2019).

Sistem kerja Plickers yaitu dengan memerlukan akses untuk membuka website www.plickers.com, aplikasi Plickers pada ponsel yang akan memanfaatkan akses kamera, serta kartu Plickers untuk seluruh peserta didik yang telah tersedia di website Plickers dan dapat diunduh secara gratis. Sehingga, guru atau pendidik hanya perlu untuk mengunduh kartu Plickers dan mencetaknya dengan media kertas. Kartu Plickers tersebut mempunyai desain QR dengan nomor unik di setiap pojok kartu yang berjumlah hingga 63 kombinasi. Artinya, penilaian hasil belajar dengan Plickers ini dapat diikuti oleh peserta didik dengan jumlah maksimal 63 orang. Pada setiap sisi kartu terdapat label $A, B, C$, dan $D$ yang menandakan pilihan jawaban peserta didik.
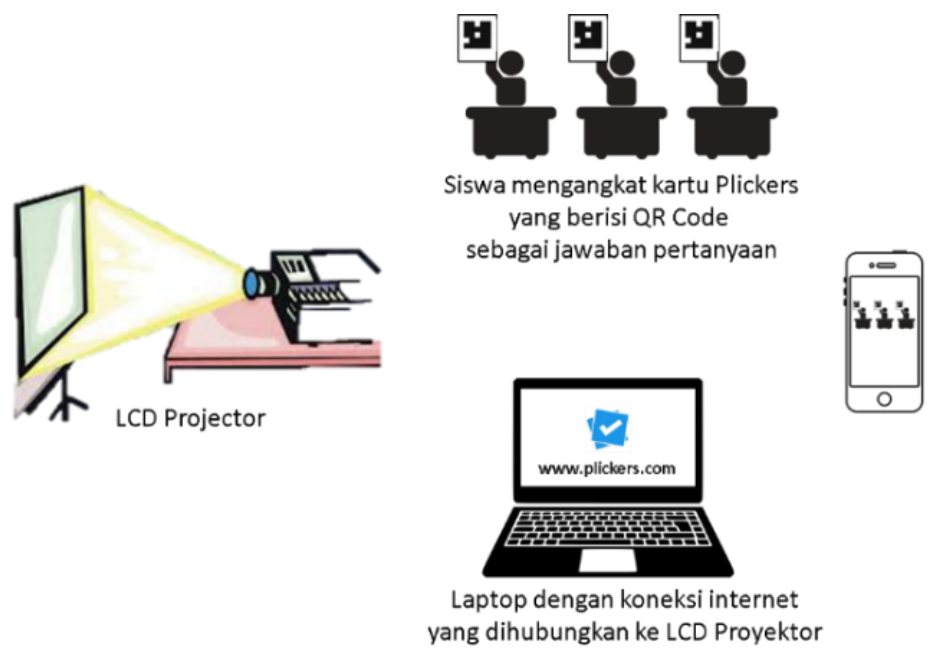

Smartphone digunakan guru untuk mengakses aplikasi Plickers untuk scan jawaban/respon siswa

\section{Gambar 1 \\ Sistem Kerja Plickers}

Kelebihan yang dimiliki Plickers yaitu memiliki tampilan antarmuka yang sederhana sehingga mudah digunakan untuk semua usia, tidak memerlukan banyak perangkat elektronik, hasil tes atau umpan balik dapat langsung disajikan kemudian disimpan dalam server web yang dapat diakses kembali kapan pun dan dimana pun, cocok digunakan untuk tes lisan maupun kuis, serta penggunaannya gratis atau tidak memerlukan biaya berlangganan (R. Jinu \& Beegum, 2019).

\section{METODE PENELITIAN}

Penelitian ini menerapkan metode penelitian deskriptif campuran (mixed research methods) antara metode kuantitatif dan metode kualitatif. Metode kuantitatif deskriptif dalam penelitian ini yaitu dengan menggunakan persentase dari analisis angket atau kuesioner. Sedangkan, metode kualitatif dengan menganalisis respon siswa terhadap tiga pertanyaan terbuka. Tiga pertanyaan terbuka digunakan sebagai data pendukung data kuantitatif. Siswa sebagai responden boleh menuliskan pendapatnya dengan bebas tanpa ada batasan jawaban.

Populasi pada penelitian ini adalah seluruh siswa SMK Kesehatan Wonosari tahun ajaran 2017/2018. Sedangkan, sampel yang digunakan terdiri dari siswa kelas XII yang keseluruhannya berjumlah 55 orang. Teknik sampling yang digunakan ialah purposive sampling karena teknik 
penentuan sampel dengan pertimbangan tingkatan kelas yang paling sering menggunakan Plickers sebagai penilaian hasil belajar pada mata pelajaran Kimia.

Instrumen yang digunakan dalam penelitian ini yaitu angket atau kuesioner yang diadopsi dari penelitian milik Elmahdi, Al-Hattami, dan Fawzi yang bertujuan untuk mengetahui efektivitas penggunaan Plickers dalam penilaian formatif untuk meningkatkan pembelajaran peserta didik di Bahrain Teachers College pada tahun 2018. Instrumen tersebut telah tervalidasi oleh dua orang ahli dalam penggunaan teknologi di bidang pendidikan. Pengisian angket atau kuesioner dilakukan secara online melalui Google Forms yang kemudian hasilnya akan dinilai dengan Skala Likert lima poin. Skala Likert dipilih karena dapat digunakan untuk mengukur sikap, pendapat, dan persepsi seseorang atau kelompok tentang kejadian atau gejala sosial.

\section{HASIL DAN PEMBAHASAN}

Bagian ini menampilkan hasil tanggapan siswa dengan menggunakan persentase dari angket persepsi dan tanggapan mereka terhadap tiga pertanyaan terbuka. Hasil jawaban dari pertanyaan terbuka yang diajukan menarik karena bukan hanya sebatas mendukung jawaban yang ditawarkan dalam kuesioner, melainkan menyoroti aspek penting lain yang berkaitan dengan penelitian ini.

Menurut (Woike, 2007), data kualitatif yang diperoleh dari pertanyaanpertanyaan terbuka merupakan ungkapan dari pemikiran terdalam, kerangka referensi, reaksi emosional dan asumsi budaya yang mungkin atau tidak mungkin diperoleh dengan metode lain. Meskipun, tanggapan yang bersifat kualitatif dari siswa mencakup berbagai aspek, peneliti menyoroti tema penting yang muncul dari tanggapan siswa. Tema-tema tersebut antara lain keterlibatan siswa, kesempatan yang sama untuk berpartisipasi, ketertarikan dan kesenangan, menghemat waktu belajar, keluar dari kebiasaan, kemudahan penggunaan, masalah jaringan dan kurangnya infrastruktur di sekolah. Hasil dari lima pertanyaan terkait pentingnya dan efektivitas penggunaan penilaian formatif dari 55 responden disajikan dalam bentuk persentase dalam tabel 1.

Tabel 1

Persentase Deskriptif untuk Pernyataan tentang Penilaian Formatif

\begin{tabular}{clccc}
\hline No & \multicolumn{1}{c}{ Pernyataan } & Persentase & Kategori \\
\hline 1 & $\begin{array}{l}\text { Penilaian harian atau penilaian } \\
\text { formatif perlu dilakukan sebagai } \\
\text { bagian integral dalam pembelajaran } \\
\text { di kelas }\end{array}$ & $83,64 \%$ & Sangat Setuju \\
\hline 2 & $\begin{array}{l}\text { Penilaian harian atau penilaian } \\
\text { formatif membantu guru untuk } \\
\text { mengidentifikasi materi atau konsep } \\
\text { yang susah dipahami siswa }\end{array}$ & $82,91 \%$ & Sangat Setuju \\
\hline 3 & $\begin{array}{l}\text { Penilaian harian atau penilaian } \\
\text { formatif dapat membantu guru } \\
\text { mengidentifikasi keterampilan yang } \\
\text { sulit diperoleh siswa }\end{array}$ & $84,73 \%$ & Sangat Setuju \\
\hline
\end{tabular}




\begin{tabular}{llll}
\hline 4 & $\begin{array}{l}\text { Penilaian harian atau penilaian } \\
\text { formatif menyediakan informasi yang } \\
\text { diperlukan untuk melakukan } \\
\text { penyesuaian ketika pembelajaran } \\
\text { berlangsung }\end{array}$ & $83,27 \%$ & Sangat Setuju \\
\hline 5 & $\begin{array}{l}\text { Penilaian harian atau penilaian } \\
\text { formatif membimbing guru dan siswa } \\
\text { dalam pembuatan keputusan tentang } \\
\text { bagaimana langkah selanjutnya untuk } \\
\text { mencapai tujuan }\end{array}$ & $88,82 \%$ & Sangat Setuju \\
\hline RERATA PERSENTASE & $\mathbf{8 4 , 0 7 \%}$ & Sangat Setuju \\
\hline Sumber : Data Penelitian, 2018
\end{tabular}

Berdasarkan tabel 1, terlihat jelas bahwa dalam penyelidikan persepsi siswa terhadap pentingnya implementasi penilaian formatif di kelas menunjukkan bahwa secara keseluruhan sejumlah $84,07 \%$ siswa sangat setuju untuk dilakukan penilaian formatif dalam proses pembelajaran.

Alasan siswa yang terungkap dari jawaban pertanyaan terbuka yaitu dengan penilaian formatif atau penilaian harian setiap akhir pembahasan suatu topik tertentu mengharuskan siswa untuk lebih bersungguh-sungguh dalam proses pembelajaran di kelas. Apabila tidak serius, maka mereka merasa khawatir akan mendapat nilai yang kurang baik dalam penilaian formatif. Selain itu, dengan hasil penilaian formatif yang ditampilkan kepada siswa dapat dijadikan bahan evaluasi bagi siswa karena siswa akan memperoleh feedback secara langsung terkait nilai yang diperolehnya. Apabila nilai yang diperoleh baik maka siswa akan mendapatkan kepuasan dan menjadi lebih termotivasi untuk lebih semangat belajar. Sedangkan, jika siswa mendapat nilai yang belum membuat mereka puas, maka siswa akan termotivasi untuk lebih giat belajar dan lebih memperhatikan penjelasan guru di kelas. Hal ini sejalan dengan tujuan penilaian formatif yaitu untuk menentukan apa yang harus ditingkatkan agar pembelajaran lebih sistematis, efektif, dan efisien.
Berdasarkan tabel 1, dapat diketahui rincian untuk persepsi siswa terhadap penilaian formatif membantu guru dalam mengidentifikasi materi/konsep yang susah dipahami siswa dengan persentase $82,91 \%$ dan persepsi siswa terhadap penilaian formatif untuk mengidentifikasi keterampilan yang sulit diperoleh siswa dengan persentase $84,73 \%$. Selanjutnya, terkait persepsi siswa dalam menyediakan informasi yang diperlukan untuk melakukan penyesuaian ketika pembelajaran berlangsung dengan persentase $83,27 \%$, dan dalam membimbing guru dan siswa dalam pembuatan keputusan tentang bagaimana langkah selanjutnya untuk mencapai tujuan dengan persentase sejumlah $88,82 \%$. Hasil ini juga menunjukkan bahwa siswa setuju dengan penilaian formatif perlu dilakukan dalam pembelajaran di kelas perlu dilakukan sebagai bagian integral dalam pembelajaran di kelas dengan persentase $83,64 \%$. Guru dan siswa dapat mengetahui secara langsung nilai hasil penilaian formatif dengan memanfaatkan Plickers. Guru juga dapat membandingkan nilai hasil penilaian formatif dalam kurun waktu tiap bulan, tiap semester, atau tiap tahunnya dengan melihat pada bagian scoresheet di website plickers.com. Dengan begitu, guru dapat mengidentifikasi materi atau konsep apa saja yang susah dipahami siswa dan juga keterampilan apa saja yang sulit diperoleh 
siswa. Sehingga, guru dapat menyediakan informasi dan mengambil keputusan terkait langkah apa saja yang selanjutnya dilakukan guru untuk meningkatkan proses pembelajaran. Selanjutnya, hasil dari pernyataan terkait penggunaan teknologi dalam penilaian hasil belajar dari 55 responden disajikan dalam bentuk persentase dalam tabel 2

Tabel 2

Persentase Deskriptif untuk Penggunaan Teknologi

\begin{tabular}{|c|c|c|c|}
\hline No & Pernyataan & Persentase & Kategori \\
\hline 6 & $\begin{array}{l}\text { Penilaian formatif berbasis teknologi } \\
\text { dalam pembelajaran di kelas } \\
\text { berdampak terhadap hasil belajar siswa }\end{array}$ & $77,45 \%$ & Setuju \\
\hline
\end{tabular}

Sumber : Data Penelitian, 2018

Berdasarkan tabel 2, dapat diketahui bahwa sebanyak $77,45 \%$ siswa dari 55 responden setuju bahwa penggunaan teknologi dalam penilaian formatif di pembelajaran berdampak positif pada hasil belajar siswa. Hasil ini sesuai dengan hasil penelitian lain bahwa generasi baru (millennials) memang suka dengan penggunaan teknologi dalam kehidupan mereka sehari-hari dan menggunakan teknologi memiliki efek positif pada pembelajaran siswa (Schell, Lukoff, \& Mazur, 2013). Untuk pertanyaan terbuka yang diajukan kepada siswa terkait persepsi mereka tentang bagaimana efektivitas penggunaan Plickers dalam proses pembelajaran di kelas menunjukkan bahwa mayoritas siswa setuju apabila penggunaan Plickers dalam proses pembelajaran di kelas sangat efektif. Pendapat dari salah satu siswa sebagai responden mengungkapkan bahwa, "sangat mudah, dan membuat asik dalam pembelajaran dan langsung mengetahui hasilnya".
Berdasarkan pendapat siswa tersebut, ternyata siswa merasa bahwa penggunaan Plickers membuat mereka senang dengan mengungkapkannya dengan kata "asik". Pendapat lain mengungkapkan bahwa, "sangat membantu dan tidak menyusahkan muridmuridnya, justru malah menggugah semangat untuk belajar dalam proses belajar mengajar sehingga persaingan dalam belajar disekolah pun bertambah dengan sendirinya". Berdasarkan pendapat siswa tersebut diketahui bahwa dengan penggunaan Plickers dapat menggugah semangat untuk lebih aktif dalam proses pembelajaran dan dapat membuat suasana di kelas menjadi kompetitif.

Hasil dari 7 pertanyaan terkait Plickers, serta 4 pertanyaan yang menanyakan rencana penggunaan Plickers dalam pembelajaran di kelas apabila mereka menjadi seorang guru atau pendidik di kemudian hari dari 55 responden disajikan dalam bentuk persentase dalam tabel 3.

Tabel 3

Persentase Deskriptif untuk Penggunaan Plickers

\begin{tabular}{clcc}
\hline No & \multicolumn{1}{c}{ Pernyataan } & Persentase & Kategori \\
\hline 7 & $\begin{array}{l}\text { Plickers membantu siswa untuk mendapatkan umpan balik } \\
\text { (feedback) }\end{array}$ & $83,27 \%$ & $\begin{array}{c}\text { Sangat } \\
\text { Setuju }\end{array}$ \\
\hline 8 & $\begin{array}{l}\text { Plickers dapat digunakan dengan mudah oleh guru dalam } \\
\text { pembelajaran di kelas }\end{array}$ & $77,09 \%$ & Setuju
\end{tabular}




\begin{tabular}{|c|c|c|c|}
\hline 9 & $\begin{array}{l}\text { Plickers memungkinkan guru untuk mendapatkan data } \\
\text { penilaian formatif secara real-time tanpa harus } \\
\text { menggunakan perangkat dari siswa }\end{array}$ & $80,36 \%$ & $\begin{array}{l}\text { Sangat } \\
\text { Setuju }\end{array}$ \\
\hline 10 & $\begin{array}{l}\text { Plickers membantu dalam penyimpanan hasil jawaban } \\
\text { siswa untuk kemudian hari }\end{array}$ & 81 & $\begin{array}{l}\mathrm{Sa} \\
\mathrm{Se}\end{array}$ \\
\hline 11 & $\begin{array}{l}\text { Plickers membantu menampilkan hasil jawaban siswa } \\
\text { dalam bentuk grafik }\end{array}$ & 79 & Setuju \\
\hline 12 & $\begin{array}{l}\text { Siswa menyukai ketika guru menggunakan Plickers di } \\
\text { kelas }\end{array}$ & $80,00 \%$ & \\
\hline 13 & $\begin{array}{l}\text { Siswa merasa nyaman dalam memberikan jawaban ketika } \\
\text { guru menggunakan Plickers di kelas }\end{array}$ & $3 \%$ & \\
\hline 14 & $\begin{array}{l}\text { Plickers memungkinkan siswa untuk menyimpulkan } \\
\text { jawaban apa yang salah dan alasannya }\end{array}$ & $3 \%$ & $\begin{array}{l}\text { Sangat } \\
\text { Setuju }\end{array}$ \\
\hline 15 & $\begin{array}{lllll}\begin{array}{l}\text { Siswa merasa tertarik ketika Plickers pertama kali } \\
\text { digunakan }\end{array} & & & \\
\end{array}$ & $7 \%$ & Setuju \\
\hline 16 & $\begin{array}{l}\text { Plickers membantu dalam mengetahui perkembangan } \\
\text { siswa dan pemahaman konteks }\end{array}$ & $77,82 \%$ & Setuju \\
\hline 17 & $\begin{array}{l}\text { Saya berencana menggunakan Plickers apabila saya } \\
\text { menjadi seorang guru }\end{array}$ & $77,82 \%$ & Setuju \\
\hline & RERATA PERSENTASE & $80,86 \%$ & $\begin{array}{l}\text { Sangat } \\
\text { Setuju }\end{array}$ \\
\hline
\end{tabular}

Sumber : Data Penelitian, 2018

Berdasarkan tabel 3, dapat diketahui bahwa secara keseluruhan sebanyak $80,86 \%$ dari 55 responden sangat setuju dengan penggunaan Plickers dalam membantu proses pembelajaran. Rinciannya adalah sebanyak $83,27 \%$ dari 55 siswa sangat setuju terhadap penggunaan Plickers dapat membantu siswa untuk mendapatkan umpan balik, sebanyak $77,09 \%$ dari 55 responden setuju apabila Plickers dapat digunakan dengan mudah oleh guru, sebanyak $80,36 \%$ dari 55 responden sangat setuju apabila Plickers memungkinkan guru untuk mendapatkan data penilaian formatif secara real-time tanpa harus menggunakan perangkat dari siswa, sebanyak $81,82 \%$ dari 55 responden sangat setuju apabila Plickers membantu dalam penyimpanan hasil jawaban siswa di kemudian hari karena semua jawaban siswa akan direkapitulasi secara otomatis pada website plickers.com yang dapat diakses kembali apabila guru ingin mencetak hasilnya. Tentu hal ini memudahkan beban guru dalam rekapitulasi nilai siswa di akhir semester.

Persentase selanjutnya yaitu sebanyak 79,64 \% dari 55 responden setuju terhadap Plickers membantu menampilkan hasil jawaban siswa dalam bentuk grafik. Hal ini benar karena dalam pelaksanaan penggunaan Plickers dalam penilaian formatif, maka secara real-time akan ditampilkan grafik dari data siswa yang menjawab jawaban benar dan juga salah. Hasil ini berkaitan dengan $82,18 \%$ sangat setuju jika Plickers memungkinkan siswa untuk menyimpulkan jawaban apa yang salah dan alasannya. Terkait hal tersebut, guru dapat membahas kembali untuk setiap pilihan jawaban agar siswa lebih yakin terhadap suatu topik yang diajarkan. Siswa juga mengungkapkan dalam menjawab pertanyaan terbuka bahwa, "penggunaan Plickers efektif, siswa bisa bertanya lagi jiga tidak paham atau kita bisa tau seberapa pahamnya siswa". 
Selanjutnya, sebanyak $80,00 \%$ dari 55 responden sangat menyukai apabila guru menggunakan Plickers di kelas. Hasil tersebut akan berkaitan dengan 90,18\% dari 55 responden merasa sangat nyaman dalam memberikan jawaban ketika guru menggunakan Plickers di kelas. Sebanyak $79,27 \%$ dari 55 responden merasa tertarik ketika Plickers pertama kali digunakan. Alasan yang terungkap dari jawaban pertanyaan terbuka yang diajukan kepada siswa ketika ditanyakan rencana penggunaan Plickers apabila mereka menjadi guru di masa depan menunjukkan bahwa mereka akan menggunakan Plickers dengan alasan, "Alasanya agar siswa dalam belajar tidak merasa jenuh. Pastinya ada hal baru dalam cara belajar/menjawab pertanyaan".

Berdasarkan tabel 3, juga diketahui bahwa sebanyak $77,82 \%$ setuju apabila Plickers membantu dalam mengetahui perkembangan siswa dan pemahaman konteks. Selain itu, sebanyak $77,82 \%$ dari 55 responden setuju untuk menggunakan Plickers apabila di kemudian hari mereka menjadi seorang guru. Salah satu siswa mengungkapkan dalam menjawab pertanyaan terbuka yang diajukan bahwa, "Tentu saja, lya, selain efektif Plickers juga aplikasi yang bisa digunakan oleh para pengajar untuk menerapkan tes model multiple choice dengan cara yang tidak kalah serunya dengan cara yang digunakan oleh guru saya di SMK, tetapi tidak perlu dengan menyediakan komputer untuk masing-masing murid. Tidak semua sekolah dilengkapi dengan satu komputer untuk satu murid. Dan tidak semua guru bisa membuat program (yang meskipun terlihat sederhana, tetapi di belakangnya perlu keahlian programming dan networking) hanya agar bisa menjalankan sebuah tes".

Berdasarkan hasil angket persepsi yang diisi oleh 55 responden, siswa merasa bahwa penggunaan Plickers dalam penilaian hasil belajar efektif karena dapat digunakan dengan mudah oleh guru dan dapat menampilkan hasil penilaian hasilnya secara real-time. Akan tetapi, siswa juga mengungkapkan persepsinya terkait permasalahan yang dihadapi dalam penggunaan Plickers di dalam proses pembelajaran yaitu terkait koneksi internet yang harus stabil, apabila tidak stabil maka akan terjadi delay dalam merespon jawaban siswa. Siswa juga menyoroti kebutuhan listrik dalam penerapan pembelajaran dengan Plickers, mereka mengkhawatirkan apabila tidak ada aliran listrik maka penggunaan Plickers dalam penilaian hasil belajar tidak dapat terlaksana. Persepsi siswa terkait hal ini memang logis, akan tetapi terdapat solusi yang bisa dilakukan apabila guru tetap ingin menggunakan Plickers dalam penilaian hasil belajar yaitu dengan memanfaatkan kamera dari smartphone kemudian soal dan pilihan jawaban akan dibacakan oleh guru. Dengan begitu guru masih dapat menerapkan penggunaan Plickers meskipun jawaban siswa tidak dapat ditampilkan secara langsung karena guru yang harus membacakan hasilnya kepada siswa.

Siswa juga mengungkapkan dalam menjawab pertanyaan terbuka bahwa masih adanya kendala keterbacaan $Q R$ codes di kertas yang dibawa siswa dengan smartphone milik guru apabila jarak siswa dengan guru terlalu jauh dan apabila ruangan terlalu gelap karena mendung misalnya. Sehingga, berdasarkan berbagai permasalahan atau kendala yang diungkapkan siswa di atas, peneliti menyimpulkan bahwa penggunaan Plickers akan sangat bermanfaat karena efektif bagi guru dan siswa atau peserta didik dengan syarat infrastruktur listrik dan koneksi internet tersedia dengan baik dan juga kondisi ruangan kelas harus memadai.

Hasil penelitian ini relevan dengan hasil penelitian yang dilakukan pada tahun (Elmahdi dkk, 2018) yang bertujuan untuk 
mengetahui efektivitas penggunaan Plickers dalam penilaian formatif untuk meningkatkan pembelajaran peserta didik di Bahrain Teachers College yang mengungkapkan bahwa penggunaan Plickers dapat meningkatkan partisipasi siswa, menghemat waktu, menjamin peluang partisipasi siswa, dan dapat menciptakan lingkungan belajar yang menyenangkan.

Hasil dalam penelitian ini juga sesuai dengan hasil penelitian yang dilakukan oleh (Gurisik \& Demirkan, 2019) di Turkey dalam International Journal of Scientific Research and Innovative Technology dengan judul "Opinions of High School Students about Plickers : One of the Online Formative Assessment Tools" yang mengungkapkan bahwa Plickers memberikan kontribusi positif untuk pelajaran ketika digunakan dalam pendidikan dan siswa merasa pelajaran dengan menggunakan Plickers menjadi menyenangkan. Para siswa juga dapat mengetahui jawaban yang benar dan salah secara instan untuk selanjutnya memperbaiki kesalahan mereka tersebut. Selain itu, sejumlah besar siswa sekolah menengah atas di Turkey berpikir bahwa mereka harus belajar lebih banyak untuk meningkatkan keberhasilan mereka dalam tes dengan Plickers. Berkat Plickers, siswa juga lebih banyak berpartisipasi di kelas.

Hasil dalam penelitian ini juga relevan dengan hasil penelitian yang dilakukan oleh (R. Jinu \& Beegum, 2019) dalam International Journal of Recent Technology and Engineering (IJRTE) yang berjudul "Plickers : A Tool for Language Assessment in the Digital Age" yang mengungkapkan bahwa siswa merasa senang dengan penggunaan Plickers dalam penilaian hasil belajar karena sederhana dan mudah digunakan dalam pembelajaran. Guru juga dapat secara langsung membuat rencana pembelajaran remedial untuk siswa karena hasil penilaian dapat diketahui secara langsung.

\section{E. KESIMPULAN}

Hasil penelitian menunjukkan bahwa mayoritas siswa percaya akan pentingnya penilaian hasil belajar dengan Plickers karena siswa akan mendapat umpan balik secara langsung sehingga dapat digunakan dengan mudah sebagai bahan evaluasi pembelajaran yang efektif. Selain itu, penggunaan Plickers dalam penilaian hasil belajar dapat menciptakan lingkungan belajar yang aktif dan menyenangkan.

Berdasarkan kesimpulan yang diperoleh, guru dapat mengintegrasikan teknologi khususnya Plickers dalam penilaian hasil belajar karena guru dapat berhemat dalam biaya operasional karena guru tidak perlu mencetak lembar soal dan juga lebih efektif dan efisien karena hasil penilaian formatif dapat langsung diketahui oleh guru maupun siswa secara real-time dan otomatis dengan Plickers dengan syarat infrastruktur listrik dan koneksi internet tersedia dengan baik dan juga kondisi ruangan kelas harus memadai.

Bagi peneliti yang ingin melakukan penelitian selanjutnya terkait penggunaan Plickers dalam penilaian hasil belajar dapat mencoba mengembangkan penelitian ini dengan membandingkan Plickers dengan aplikasi lain yang memiliki fungsi sama dalam mata pelajaran yang berbeda.

\section{DAFTAR PUSTAKA}

Andri, T. (2018). Evolusi Guru dan Sekolah Abad 21. Sukabumi: CV. Jejak Publisher.

Azmina, B., \& Solihah, M. (2019, Maret). Persepsi Mahasiswa dan Instruktur tentang Technological Pedagogical Content Knowledge (TPACK) Instruktur Bahasa Inggris di Indonesia. Jurnal Penelitian Teknologi Pendidikan, 17(01), 76-89. 
Daryanto, \& Karim, S. (2017). Pembelajaran Abad 21. Yogyakarta: Gava Media.

Elmahdi, I., Al-Hattami, A., \& Fawzi, H. (2018, April). Using Technology for Formative Asessment to Improve Students' Learning. TOJET: The Turkish Online Journal of Educational Technology, 17(2), 4-5.

Gurisik, A., \& Demirkan, O. (2019). Opinions of High School Students about Plickers : One of the Online Formative Assessment Tools. International Journal of Scientific Research and Innovative Technology, 6(1), 12.

Kamus Besar Bahasa Indonesia. (2019). Retrieved from Kamus Besar Bahasa Indonesia (KBBI): www.kbbi.web.id/

Kementerian Pendidikan dan Kebudayaan. (2017). Panduan Penilaian untuk Sekolah Menengah Atas. Jakarta: Direktorat Jenderal Pendidikan Dasar dan Menengah.

Kent, D. (2019). Plickers and the Pedagogical Practicality of Fast Formative Assessment. Teaching English with Technology, 19(3), 90-104.

King, L. (2012). Psikologi Umum: Sebuah Pandangan Apresiatif Buku 2. Jakarta: Salemba Humanika.

Michael, E. A., Ejeng, I. A., Udit, M. A., \& Yunus, M. M. (2019, February 08). The Use of Plickers for Language Assessment of Reading Comprehension. International Journal of Academic Research in Business \& Social Sciences, 9(1), 638-645. doi:10.6007/IJARBSS/v9-i1/5464

Nurhadi, \& Suwardi. (2010). Evaluasi Pembelajaran yang Efektif dan Menyenangkan. Jakarta: Multi Kreasi Satu Delapan.

Preszler, R. W., Dawe, A. L., Shuster, C. B., \& Shuster, M. (2007). Assessment of the Effects of Student Response Systems on Student Learning and Attitudes Over a Broad Range of Biology Courses. CBE Life Sciences Education, 6(1), 29-41. doi:10.1187/cbe.06-090190

R. Jinu, S., \& Beegum, S. (2019, July). Plickers: A Tool for Language Assessment in the Digital Age. International Journal of Recent Technology and Engineering (IJRTE), 8(2), 166-171.

Riduwan. (2007). Skala Pengukuran Variabel-Variabel Penelitian. Bandung: Alfabeta.

Schell, J., Lukoff, B., \& Mazur, E. (2013, February). Catalyzing Learner Engagement using Cutting-Edge Classroom Response Systems in Higher Education. Cutting-Edge Technologies in Higher Education, 233-261.http://doi.org/10.1108/S20449968(2013)000006E011

Slameto. (2010). Belajar dan Faktor yang Mempengaruhinya. Jakarta: Rineka Cipta.

Solmaz, E., \& Cetin, E. (2017, August). Ask-Response-Play-Learn: Students' Views on Gamification Interactive Response Systems. Journal of Educational Studies in the World, 7(3), 28-40.

Thoha, M. (2009). Perilaku Organisasi. Bandung: PT. Raja Grafindo Persada.

Widoyoko, S. (2017). Evaluasi Program Pembelajaran: Panduan Praktis Bagi Pendidik dan Calon Pendidik. Yogyakarta: Pustaka Belajar.

Woike, B. A. (2007). Content Coding of Open-Ended Responses. In R. W. Robins, R. C. Fraley, \& R. F. Krueger, Handbook of Research Methods in Personality Psychology (pp. 292-307). New York: Guilford Press. 